\title{
PETROGRAPHY OF SANDSTONE OF THE LUMSHIWAL FORMATION FROM EASTERN HAZARA, KHYBER PAKHTUNKHWA, PAKISTAN: IMPLICATIONS FOR PROVENANCE, DIAGENESIS AND ENVIRONMENTS OF DEPOSITION
}

\author{
Yasin Rahim*, M. Sabir Khan, Saleem Mughal \\ Northwest Minerals PVT LTD Peshawar, Pakistan. \\ *Corresponding Author Email: yasinrahim55@gmail.com
}

This is an open access article distributed under the Creative Commons Attribution License, which permits unrestricted use, distribution, and reproduction in any medium, provided the original work is properly cited.

\section{ARTICLE DETAILS}

\section{Article History:}

Received 26 June 2018

Accepted 2 July 2018

Available online 1 August 2018

\section{ABSTRACT}

\begin{abstract}
Detailed petrographically studies and microfacies analysis of the Lower Cretaceous Lumshiwal Formation from the eastern Hazara, Khyber Pakhtunkhwa Pakistan have been carried out from a number of sections. Fourteen microfacies including glauconitic sandstone have been identified. These studies have contributed towards the interpretation of its provenance, diagenetic components combined with the environment of deposit. It can help to understand the difference between the Lumshiwal formation of eastern Hazara with other type sections in KalaChita Range and Samana Range by correlating them with respect to environments of deposition.
\end{abstract}

\section{KEYWORDS}

Hazara, Mesozoic, petrographic interpretations, Lumshiwal.

\section{INTRODUCTION}

The study area lies in Lesser Himalayas in eastern Hazara fold and thrust belt (Figure 1). The area is comprised of Precambrian to Late Paleozoic met sediments, metavolcanics and Mesozoic to Cenozoic sedimentary rocks [1-10]. The rock units exposed in these areas are mostly limestone, sandstone, shale, dolomite and slates. The study areas are located on (Changla Gali section on lat. 33 57'45" N: long. $7321^{\prime} 27^{\prime \prime}$ E and Jabrian section on lat. $33^{\circ} 55^{\prime} 154^{\prime \prime} \mathrm{N}$ : long. $73^{\circ} 09^{\prime} 650^{\prime \prime}$ E) respectively. The Lumshiwal Formation is exposed along a road-cut in Changla Gali section Abbottabad and Jabrian section Haripur, situatedin eastern Hazara Khyber Pakhtunkhwa, Pakistan.

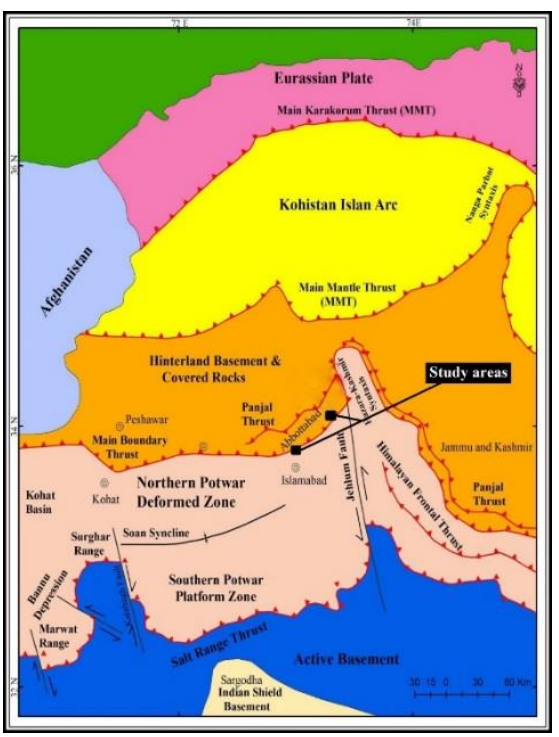

Figure 1: Tectonic framework of Northern Pakistan [11].

\section{GEOLOGICAL SETTING}

Detailed Geologically the investigated area lies on the eastern Hazara fold and thrust belt, Lesser-Himalayas. The project area represents the metamorphic rocks of Precambrian age and sedimentary rocks of Mesozoic to recent age (Table 1). The geology of Lesser-Himalayas has been studied by different workers. The Stratigraphic sequence was studied by some many researchers [1-10]. Two researcher assigned Precambrian age to these rocks [12]. The Paleontological work has been carried out on this formation [13,14]. Carried out the Paleo-environmental interpretation of Paleogene strata. A group researchers described the lithology, stratigraphy, structure and metamorphic features of the rocks of Hazara basin $[15,16]$. A researcher studied the structural events in the LesserHimalayas of Hazara fold and thrust belt [17]. They described the foraminiferal Paleogene biostratigraphy of the rock units of eastern Hazara [17]. Previous workers have carried out reconnaissance of geological investigation of the Jabrian section. The purpose of this study is to carry out detailed petrological analysis of sandstone of the Lumshiwal Formation in Jabrian section. 
Table 1: Generalized Stratigraphy of the Study Area [18]

\begin{tabular}{|c|c|c|}
\hline Formation & Age & Characteristics \\
\hline Alluvium & Quaternary & $\begin{array}{l}\text { Rounded to sub-rounded boulders, cobbles, pebbles, gravels of igneous, } \\
\text { metamorphic and sedimentary rocks embedded loosely in a matrix of sand, } \\
\text { silt and clay. }\end{array}$ \\
\hline \multicolumn{3}{|l|}{ Unconformity } \\
\hline \begin{tabular}{|l} 
Murree \\
Formation
\end{tabular} & Early Miocene & $\begin{array}{l}\text { Greenish sandstone, reddish shale, claystone, fine to medium grained. Calcite } \\
\text { and quartz veins are common. }\end{array}$ \\
\hline \multicolumn{3}{|l|}{ Unconformity } \\
\hline $\begin{array}{l}\text { Kuldana } \\
\text { Formation }\end{array}$ & $\begin{array}{l}\text { Early-Middle } \\
\text { Eocene }\end{array}$ & $\begin{array}{l}\text { Variegated shale, siltstone and calcareous sandstone which are greenish grey, } \\
\text { fine to medium grained, highly fractured Quartz veins are present. }\end{array}$ \\
\hline \begin{tabular}{|l|} 
Chorgali \\
Formation
\end{tabular} & Early Eocene & $\begin{array}{l}\text { Pale to light grey thinly bedded limestone and dark brown to black Shale. } \\
\text { Nodularity is absent. }\end{array}$ \\
\hline $\begin{array}{l}\text { Margalla Hill } \\
\text { Limestone }\end{array}$ & Early Eocene & $\begin{array}{l}\text { Dark grey to black, fine to medium grained, nodular, highly fossiliferous, } \\
\text { highly jointed and fractured limestone. Quartz veins are present. }\end{array}$ \\
\hline $\begin{array}{l}\text { Patala } \\
\text { Formation }\end{array}$ & $\begin{array}{l}\text { Late } \\
\text { Paleocene }\end{array}$ & $\begin{array}{l}\text { Creamish to dark brown splintery shale fine to medium grained, nodular } \\
\text { limestone. }\end{array}$ \\
\hline \begin{tabular}{|l|l|l} 
Lockhart \\
Limestone
\end{tabular} & $\begin{array}{l}\text { Early-Middle } \\
\text { Paleocene }\end{array}$ & $\begin{array}{l}\text { Dark grey to black, fine to medium grained, nodular, highly fossiliferous } \\
\text { limestone }\end{array}$ \\
\hline $\begin{array}{l}\text { Hangu } \\
\text { Formation }\end{array}$ & $\begin{array}{l}\text { Early } \\
\text { Paleocene }\end{array}$ & $\begin{array}{l}\text { Coal seams, medium to coarse grained, ferruginous, sandstone, fireclay, dark } \\
\text { color. }\end{array}$ \\
\hline \multicolumn{3}{|l|}{ Unconformity } \\
\hline Kawagarh Formation & $\begin{array}{l}\text { Late } \\
\text { Cretaceous }\end{array}$ & Light to dark grey, fine grained, planktonic limestone. \\
\hline $\begin{array}{l}\text { Lumshiwal } \\
\text { Formation }\end{array}$ & Early Cretaceous & $\begin{array}{l}\text { Rusty brown, grey and yellowish, fine to coarse grained, highly fractured } \\
\text { sandstone. Quartz veins are present. }\end{array}$ \\
\hline Chichali Formation & \begin{tabular}{|l|} 
Early \\
Cretaceous
\end{tabular} & Dark shales with coal seams. \\
\hline $\begin{array}{l}\text { Samana Suk } \\
\text { Formation }\end{array}$ & Jurassic & Light grey, fine grained oolitic limestone. \\
\hline \multicolumn{3}{|l|}{ Unconformity } \\
\hline $\begin{array}{l}\text { Abbottabad } \\
\text { Formation }\end{array}$ & Cambrian & $\begin{array}{l}\text { Light to dark grey, fine grained, highly fractured cherty and stromatolitic } \\
\text { dolomite, and dolomitic limestone. }\end{array}$ \\
\hline \multicolumn{3}{|l|}{ Unconformity } \\
\hline $\begin{array}{l}\text { Hazara } \\
\text { Slates }\end{array}$ & Precambrian & Hazara slates are fine grained, dark brown to black. Quartz veins are present. \\
\hline
\end{tabular}

\section{MATERIAL AND METHODS}

The current study deals with petrographic interpretations of sandstone of Lumshiwal Formation from Jabrian section. The sample location map of the area was prepared on Topo sheets nos. $43 \mathrm{~F} / 8$ and $43 \mathrm{G} / 1$ of the Survey of Pakistan (Figure 2). ten representative samples of sandstone of the Lumshiwal Formation were selected for petrographic studies, among them 8 sandstone samples were selected for the preparation of thin sections and 2 sandstone samples were selected for preparation of staining thin sections for porosity and permeability study. Litholog was also prepared from the petrographic studies (Figure 3). The section measurement was carried out in the study area. The section measurement was started from the upper contact of Chichali Formation to the lower contact of Kawagarh Formation. The total thickness of the Lumshiwal Formation is 21 meter in Changla Gali and 18 meter in Jabrian section (Figure 4). The thin sections study was carried out under Polarizing microscope (LEICA DM750P). Modal analysis of samples was carried out to determine the quantitative mineralogical aspects of the sandstone.

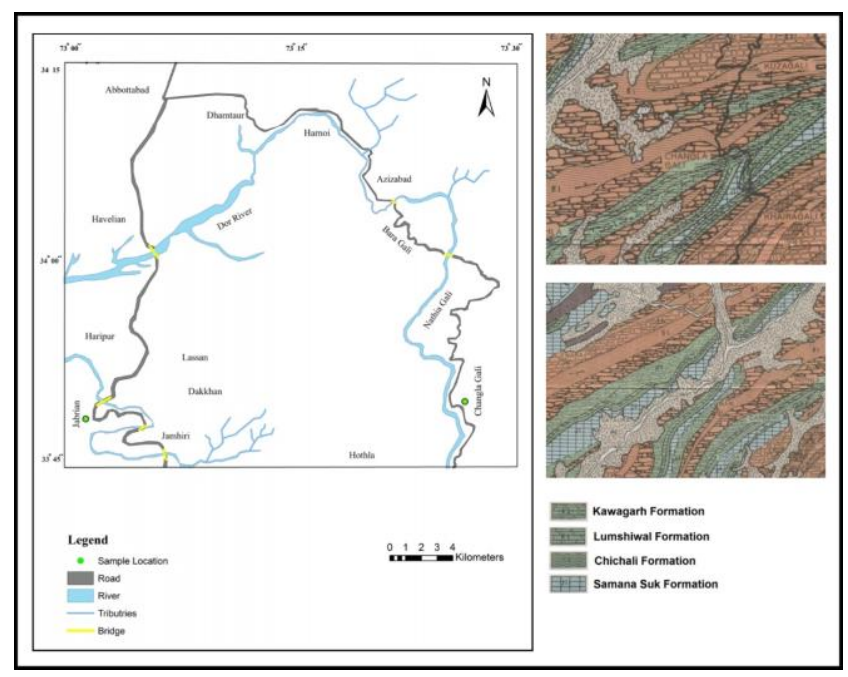

Figure 2: Sample location map of the study area. 


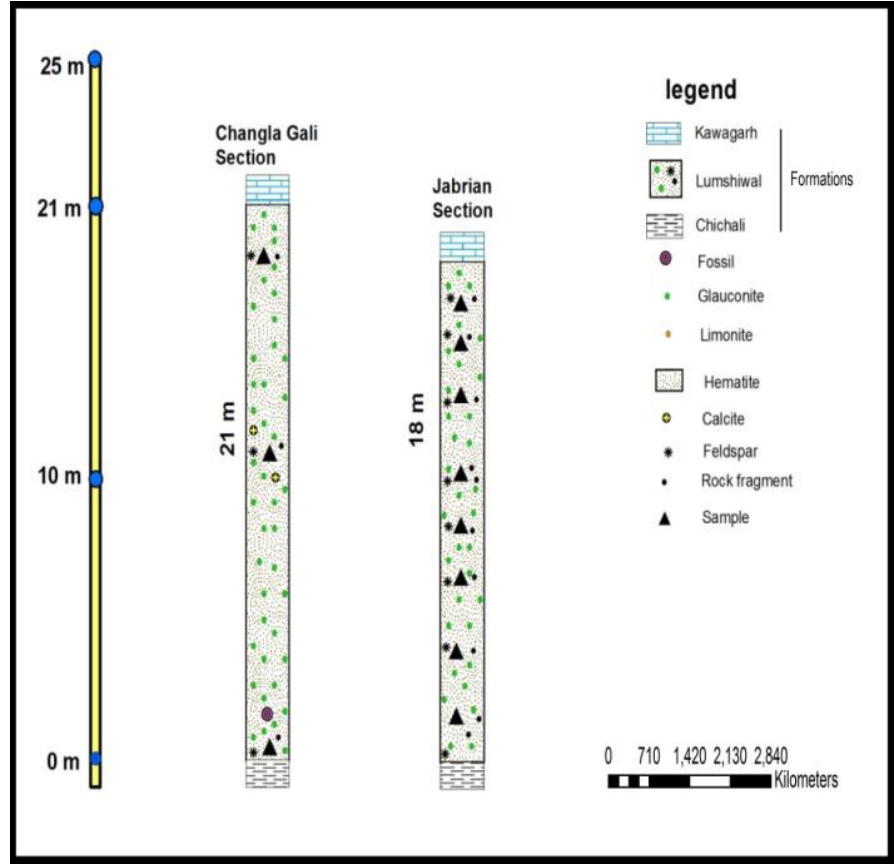

Figure 3: Lithological logs of the studied sections.

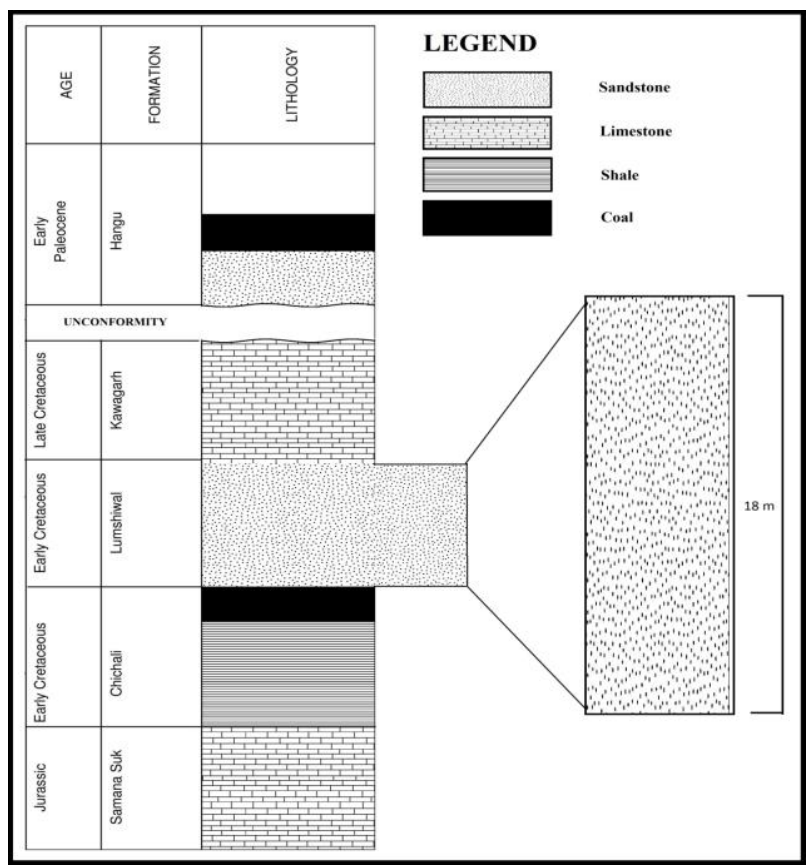

Figure 4: Measured Stratigraphic section of Jabrian area.

\section{RESULTS}

\subsection{Petrography of Sandstone of the Lumshiwal Formation}

The framework constituents of sandstone of the Lumshiwal formation are sub-angular to sub-rounded indicating long transportation. The high model proportion of quartz as compared to feldspar and rock fragments

suggests that the sandstone is mineralogically mature (Table 2). Monocrystalline quartz is abundant where as poly-crystalline quartz is in minor amount (Figure 5a) having 5 to 7 sub-grains. Feldspar is albite plagioclase (Figure 5b) and microcline (Figure 5c). The heavy minerals identified in thin sections are tourmaline (Figure $5 \mathrm{~d}$ ), zircon inclusions in quartz grains

Table 2: Modal mineralogical data of sandstone of the Lumshiwal Formation of Jabrian section Haripur.

\begin{tabular}{|c|c|c|c|c|c|c|c|c|}
\hline Samples & JbL-1 & JbL-2 & JbL-3 & JbL-4 & JbL-5 & JbL-8 & JbL-7 & JbL-6 \\
\hline Quartz & 75 & 80 & 80 & 80 & 80 & 70 & 75 & 70 \\
\hline Poly-crystalline & 2 & 3 & 2 & 2 & 3 & 3 & 2 & 2 \\
\hline Feldspar & 4 & 4 & 2 & 3 & 4 & 4 & 3 & 2 \\
\hline Perthite & $\mathrm{Tr}$ & $\mathrm{Tr}$ & $\mathrm{Tr}$ & $\mathrm{Tr}$ & $\mathrm{Tr}$ & $\mathrm{Tr}$ & $\mathrm{Tr}$ & $\mathrm{Tr}$ \\
\hline Pericline & - & $\mathrm{Tr}$ & $\operatorname{Tr}$ & $\operatorname{Tr}$ & - & $\mathrm{Tr}$ & $\operatorname{Tr}$ & $\operatorname{Tr}$ \\
\hline Rock Fragments & 1 & 1 & 1 & 2 & 2 & 1 & 1 & 2 \\
\hline Sandstone & $\operatorname{Tr}$ & - & - & $\operatorname{Tr}$ & - & - & $\mathrm{Tr}$ & $\mathrm{Tr}$ \\
\hline Tourmaline & $\operatorname{Tr}$ & $\mathrm{Tr}$ & $\operatorname{Tr}$ & $\operatorname{Tr}$ & $\operatorname{Tr}$ & $\operatorname{Tr}$ & $\operatorname{Tr}$ & $\operatorname{Tr}$ \\
\hline Zircon & $\operatorname{Tr}$ & $\operatorname{Tr}$ & $\operatorname{Tr}$ & - & $\operatorname{Tr}$ & - & $\operatorname{Tr}$ & - \\
\hline Epidote & $\mathrm{Tr}$ & - & $\mathrm{Tr}$ & $\operatorname{Tr}$ & $\mathrm{Tr}$ & $\operatorname{Tr}$ & $\operatorname{Tr}$ & - \\
\hline Muscovite & $\mathrm{Tr}$ & $\mathrm{Tr}$ & $\mathrm{Tr}$ & $\operatorname{Tr}$ & $\mathrm{Tr}$ & $\mathrm{Tr}$ & $\mathrm{Tr}$ & $\mathrm{Tr}$ \\
\hline Sphene & - & - & - & $\operatorname{Tr}$ & - & - & - & - \\
\hline Glauconite & 7 & - & - & - & - & - & - & 15 \\
\hline \multicolumn{9}{|l|}{ Cement } \\
\hline Hematite & 3 & 7 & 10 & 8 & 5 & 20 & 15 & 7 \\
\hline Calcite & - & - & - & 1 & - & - & - & - \\
\hline
\end{tabular}



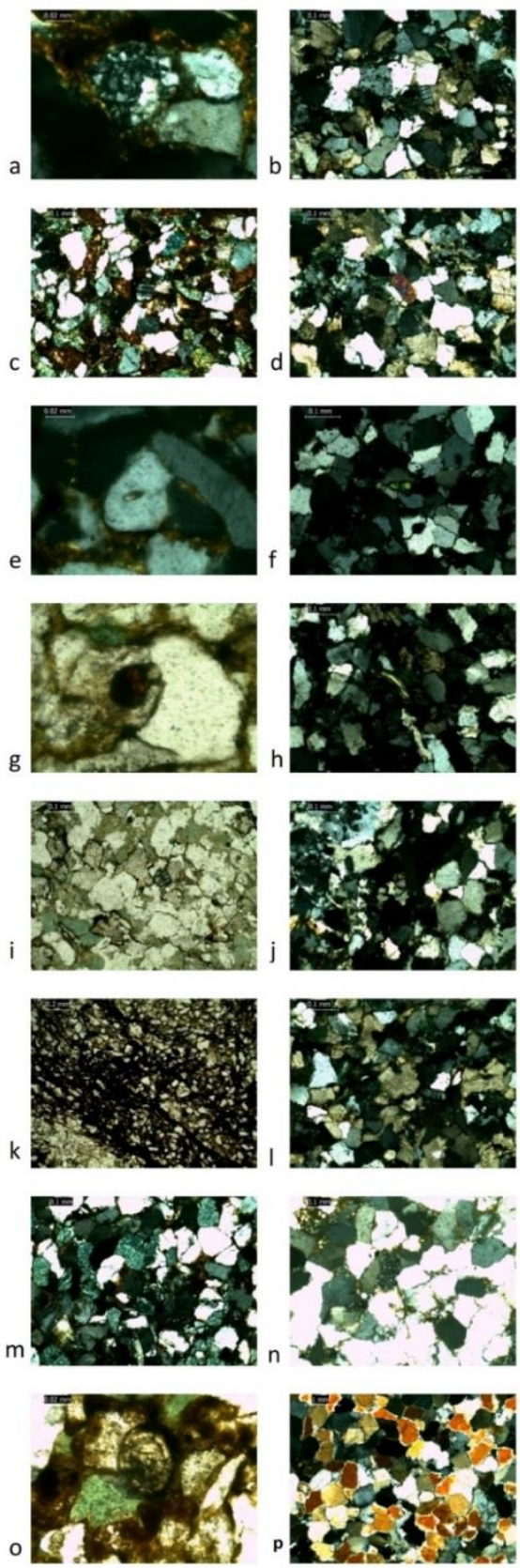

Figure 5: Photomicrograph showing, (a) poly-crystalline quartz grain, (b) albite plagioclase grain, (c) microcline grain, (d) tourmaline grain, (e) zircon inclusion in quartz grain, (f) epidote grain, (g) rutile grain, (h) muscovite flake, (i) monazite grain, (j) sphene grain, (k) hematite cement, (l) calcite cement, (m) glauconite pellets, (n) sandstone clast, (o) ammonoide fossil and (p) planner, concavo-convex and sutured contacts between quartz grains.

\subsection{Tectonic Provenance}

In the QFL ternary diagram of a group researchers, the compositional framework grain data of Jabrian section plot in the craton interior field (Figure 6) [20]. This suggested that the detritus for this sandstone was

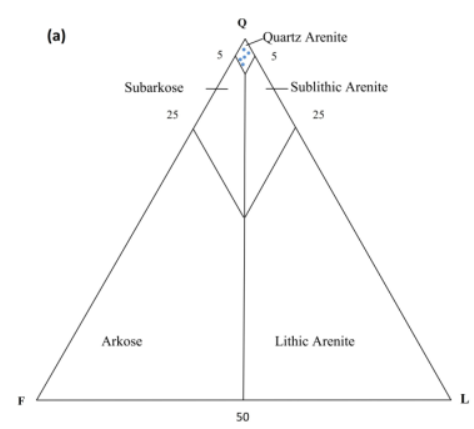

derived from the stable continental craton. The stable craton rocks are Indian craton in south east where a variety of igneous plutonic rocks, meta-sedimentary rocks and sandstones are exposed. These craton rocks were eroded, transported and then deposited in the depositional basin of Hazara [21].

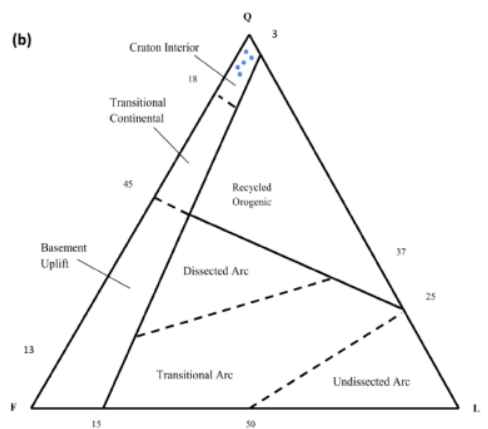

Figure 6: (a) QFL Modal composition and (b) QFL Provenance discrimination diagram for source region of sandstone of the Lumshiwal Formation of Jabrian section Haripur [23] 


\subsection{Diagenetic Modifications}

Silica as quartz overgrowth and formation of sutured, concavo-convex grain contacts (Figure 5p). Formation of calcite cement, presence of glauconite mineral which is a product of alteration all these features indicates diagenetic modifications.

\subsection{Environment of Deposition}

The sandstone of the Lumshiwal Formation exhibits features like abundance of quartz, limitation of feldspar and rock fragments, total absence of matrix, thick bedded character, upward coarsening of grains and the presence of glauconite mineral. These features suggest that the depositional environment may be reducing and shallow marine (Figure 7). The bioclasts are Ammonoides also indicate deposition of sandstone in shallow marine environment. The provenance source of clastic material may have been derived from Southeast Indian craton. The clastic material was transported and deposited in the shallow shelf sea of the Northwest part of Indian plate, which is currently the area under Axial Belt in Pakistan. The seaward advancement of the shore line begins in the Early Cretaceous resulting in near shore deposition of Lumshiwal Formation [3].

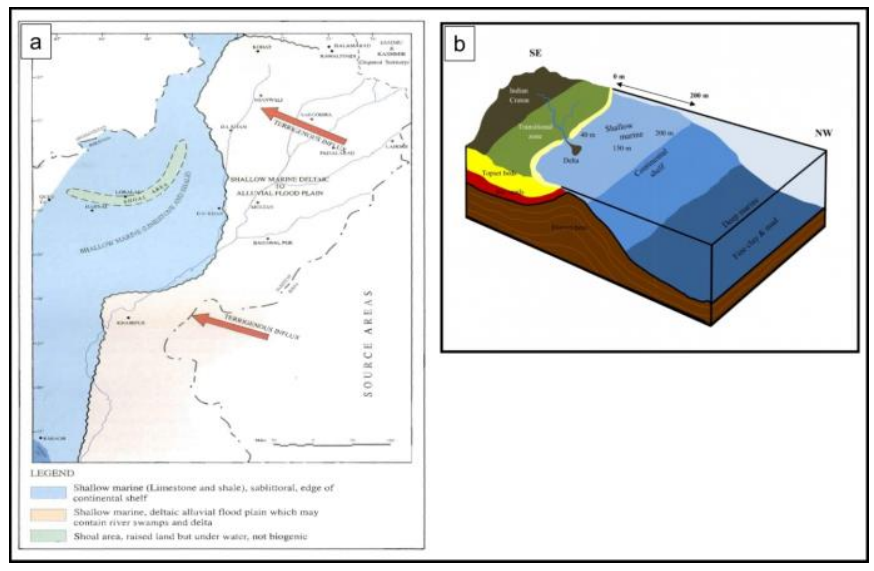

Figure 7: (a) Paleogeographic sketch map of Early Cretaceous [3]. (b) Deposition modal of the Lumshiwal Formation.

\subsection{Porosity and Permeability}

The porosity analysis of three sandstone samples was carried out by thin section studies. The porosity of sandstone outcrop sample by thin section study is less than $3 \%$ which is negligible. Routine core analysis was also carried out to find porosity and permeability of sandstone samples. For this purpose, three sandstone sample of the Lumshiwal Formation were collected from outcrop. These samples were tested in Hydrocarbon Development Institute of Pakistan (HDIP) laboratory, Islamabad. Porosity tests were performed at 500 psi (overburden pressure). Whereas the permeability tests were performed at 400 psi (overburden pressure), both porosity and permeability of sandstone was recorded negligible.

\section{DISCUSSION}

The lithology of the Lumshiwal formation in eastern Hazara is comprised of sandstone. The sandstone is hard and compact. It is highly fractured and deformed due to deformation caused by tectonic activities. The outcrop of

sandstone exhibits grey, rusty brown and greenish colors. Calcite veins were also observed on the outcrop. The basal contact of the Lumshiwal Formation is with Early Cretaceous Chichali Formation and the upper contact is with Late Cretaceous Kawagarh Formation. It is mainly thinly bedded and is $21 \mathrm{~m}$ in Changla Gali section and $18 \mathrm{~m}$ thick in Jabrian section in the study area.

The petrographic studies of the Lumshiwal sandstone in the study areas suggest that, major constituent of this sandstone is quartz. The quartz grains are sub-angular to sub-rounded which suggests that the quartz grains have been transported from a long distance. The quartz grains are mainly mono-crystalline with a minor amount of poly-crystalline quartz.
The poly-crystalline quartz is comprised of 5 to 7 sub-grains which suggest the source probably to be metamorphic rocks. The mono-crystalline quartz is mainly non-undulose which suggests the source to be igneous rock and inclusions of zircon shows granitic rocks origin. The quartz grains exhibit planner, sutures and concavo-convex contacts. The planner contacts indicate igneous origin whereas the sutured contact indicates metamorphic origin [21].

Feldspar is also observed in the Lumshiwal sandstone. Plagioclase and alkali feldspar indicates its derivation from acidic plutonic rocks. The microcline and alkali feldspar indicate metamorphic and igneous plutonic rocks [22]. The perthite alkali feldspar indicates alkali rich igneous and metamorphic origins.

Rock fragment is another major constituent in sandstone composition. Sedimentary and igneous rock fragments were observed in the sandstone of the Lumshiwal Formation in the eastern Hazara [21,22]. The sedimentary rock fragments were of sandstone and siltstone which may be derived from Precambrian, Paleozoic and Mesozoic successions of sandstone in Indian craton. The igneous rock fragments may be derived from Precambrian plutonic rocks and Paleozoic quartzite successions of the Indian carton. Sandstone rock fragment is different from the Lumshiwal sandstone as indicated by lack of glauconite, hematite cement which could possibly from ancient sandstones present in the Indian shield. The rock fragments were derived from outside basin of deposition.

Hematite cement indicates oxidizing environment, calcite indicates alkaline conditions. There is no previous record of calcite in the sandstone unit of the Lumshiwal Formation. Glauconite indicates the reducing environments during deposition of sandstone of the Lumshiwal formation. Limonite is also identified in the sandstone; there is no previous record of limonite in sandstone of the Lumshiwal Formation [23].

In accessory minerals tourmaline grains indicates igneous or metamorphic rocks origin. Zircon inclusion in quartz grain indicates Precambrian shield rocks. Rutile mineral is an important source of Titanium and is possibly derived from metamorphic origin. Mineral sphene is also identified in the sandstone and there is no previous record of sphene in sandstone of the Lumshiwal Formation. Epidote indicates to the source acidic plutonic rocks. Muscovite is in flakes form and is derived from biotite.

On the basis of provenance discrimination diagram of Dickinson source region of sandstone of the Lumshiwal Formation in the eastern Hazara by its modal mineralogical data fall in the field of craton interior [23].

\section{CONCLUSION}

The following conclusions are drawn on the basis of present research:

1. The presence of fossils and glauconite in sandstone of the Lumshiwal Formation. The abundance of quartz, limitation of feldspar and rock fragments, total absence of matrix, thick bedded character suggest the environment of deposition to be shallow marine.

2. The sandstone samples of the Lumshiwal Formation are compositionally mature and have been classified as quarts arenite on the basis of mineralogical studies.

3. Accessory minerals are tourmaline, sphene, monazite, epidote, rutile, muscovite and zircon inclusions are present in monocrystalline quartz grains suggesting sialic basement.

4. Occurrence of silica as quartz overgrowth, calcite cement and presence of glauconite which is product of alteration, presence of concavo-convex and sutured contacts of quartz grains indicates diagenetic changes.

5. The petrographic data plotted on provenance discrimination diagram shows Craton Interior.

6. The porosity and permeability of sandstone is negligible.

\section{ACKNOWLEDGMENTS}

The authors are thankful to Assistant Professor Iqbal Siddiqui, Director Institute of Geology, University of Azad Jammu and Kashmir Muzaffarabad 
for providing the necessary facilities to carry out the research work. We are thankful to Dr. Rana Asif, Deputy Director Geoscience Laboratory Islamabad, for providing facilities in preparation of thin sections and Xray diffraction analysis. We are thankful to Engineer Jam Muhammad Kashif, Hydrocarbon Development Institute of Pakistan (HDIP) laboratory, Islamabad for preparation of core samples for interpretation of porosity and permeability.

\section{REFERENCES}

[1] Middlemiss, C.S. 1896. The geology of Hazara and black mountains. Geological Survey of Pakistan, 26, 302.

[2] Danilchik, W., Shah, S.M.I. 1961. Stratigraphic nomenclature of formations in Trans-Indus Mountains, Mianwali District, West Pakistan. U.S. Geological Survey Professional Paper Report (IR) PK-33, 45.

[3] Shah, S.M.I. 1977. Stratigraphy of Pakistan. Geol., Surv. Pakistan. Mem., $12,138$.

[4] Calkins, T.W., Offield, Ali, S.T. 1969. Geology and mineral resources of southern Hazara District, West Pakistan, and parts of western Azad Kashmir., Prof. Report (IR) PK-43, 92.

[5] Fatmi, A.N. 1977. Stratigraphy of Pakistan. Geological Survey of Pakistan, 12, 29-56.

[6] Stoliczka, F. 1866. Summary of geological Observations during a visit to the provinces - Rupshu, Karnag, South Ladak, Zanskar, Suroo and Dras - of Western Tibet, 1865. Memoirs of the Geol., Surv. India. Mem., 5, 173.

[7] Latif, M.A. 1970c. Micropalaeontology of the Galis Group, Hazara, West Pakistan. Geological Map. Wein Jb. Geol., B. A., Sonderb, 15, 63-66.

[8] Ali, R., Ahsan, N., Chaudhry, M.N., Masood, K.R. 2000. Lithofacies, Microfacies, diagensis, Environment of Deposition and Palynology of Lumshiwal Formation at Kundla, Hazara Basin, Pakistan. Third South Asia Geological Congress, Lahore, Pakistan, 155.

[9] Ahsan, N., Chaudhry, M.N. 1999. Sedimentology of Lumshiwal Formation, Attock Hazara Fold and Thrust Belt, NW Lesser Himalayas Pakistan. In Terra Nostra, 14th Himalaya-Karakoram-Tibet Workshop, Germany, 4-5.

[10] Ahsan, N., Chaudhry, M.N., Khawaja, A. 2001c. Tithonian to Danian Sedimentation in Hazara Basin, Northern Pakistan. Nepal Geological Congress. No paging.
[11] Rustam, M.K., Ali, M. 1994. Preliminary Gravity Model of Western Himalayas in northern Pakistan. Kashmir. J. Geol., 11 (12), 59-65.

[12] Crawford, Davies, R.G. 1975. Ages of Pre-Mesozoic of the Lesser Himalaya, Hazara district, Northern Pakistan. Geological Magazine, 112, 509-514.

[13] Haque, A.F.M.M. 1956. The smaller Foraminifera of the Ranikot and the Laki of the Nammal Gorge, Salt Range. Geological Survey of Pakistan, 1, 300 .

[14] Iqbal, M.W.A. 1972. Bivalve and gastropod fauna from JherrukLakhra-Bara Nai (Sindh), Salt Range (Punjab) and Samana Range (NWFP). Geological Survey of Pakistan, 9, 104.

[15] Wells, N.A. 1987. Paleoenvironmental Interprtation of Paleogene strata near Kotli, Azad Kashmir, Northeastern Pakistan. Kashmir J. Geol., $5,23$.

[16] Bossart, P., Dietrich, D., Greco, A., Ottiger, R., Ramsay, J.G. 1988. The tectonic structure of the Hazara Kashmir Syntaxis southern Himalaya, Pakistan. Tectonics, 7, 273-297.

[17] Greco, A. 1991. Stratigraphy, metamorphism and tectonics of the Hazara Kashmir Syntaxis area. Kashmir J. Geol., 8 (9), 39-66.

[18] Baig, M.S., Munir, H.M. 2007. Foraminiferal biostratigraphy of Yadgar area Muzaffarabad Azad Kashmir, Pakistan. Journal of Himalayan Earth Sciences, 40, 33-40.

[19] Blatt, H., Tracey, R.J. 1996. Petrology, Igneous, Sedimentary and Metamorphic, $2^{\text {nd }}$ ed., W. H. Freeman Publisher, New York, 497.

[20] Shah, S.M.I. 2009. Stratigraphy of Pakistan. Geol., Surv. Pakistan. Mem., 22, 381.

[21] Folk, R.L. 1974. Petrology of sedimentary rocks, $2^{\text {nd }}$ ed. Hemphills press, Austin, TX.182.

[22] Pittman, E.D. 1970. Plagioclase feldspar as an indicator of provenance in sedimentary rocks. Journal of Sedimentary Research, 40, 591-598.

[23] Dickinson, W.R., Bread, L.S., Breckenridge, G.R., Erjavec, J.L., Ferguson, R.C., Inman, K. F., Knepp, R.A., Lindberg, Ryberg, P.T. 1983. Provenance of North American Phanerozoic sandstone in relation to tectonic setting. Bull. Geol., Soc. America., 94, 222-235. 